\title{
Brainstem auditory pathway of children with acute lymphoid leukemia on chemotherapy with methotrexate
}

\author{
Via auditiva em tronco encefálico de crianças com leucemia linfoide aguda em \\ quimioterapia com metotrexato \\ Renata Aparecida LEITE1', Jéssica Sales VOSGRAU', Leticia CORTEZ NETO', Nayara Pereira SANTOS, \\ Sandro Luiz de Andrade MATAS², Vicente ODONE FILHO³, Carla Gentile MATAS ${ }^{1}$
}

\begin{abstract}
Objective: Investigate the auditory pathway in the brainstem of children with acute lymphoblastic leukemia submitted to chemotherapy (by intravenous or intrathecal infusion). Methods: Fourteen children aged between 2 and 12 years with diagnosis of acute lymphoid leukemia were evaluated. The following procedures were used: meatoscopy, acoustic immitance measurements, tonal audiometry, vocal audiometry, transient otoacoustic emissions, and auditory brainstem response. Results: From the 14 children with normal auditory thresholds, 35.71\% showed an alteration in auditory brainstem response, with a predominance of hearing impairment in the lower brainstem. It was found that $80 \%$ of the children with alteration had used intrathecal methotrexate less than 30 days and that $40 \%$ had the highest cumulative intravenous methotrexate doses. Conclusion: Children with acute lymphoblastic leukemia submitted to chemotherapy, present auditory pathway impairment in the brainstem, with a predominance of a low brainstem.
\end{abstract}

Keywords: hearing; electrophysiology; precursor cell lymphoblastic leukemia-lymphoma; drug therapy; methotrexate; child.

\section{RESUMO}

Objetivo: Investigar a via auditiva em tronco encefálico de crianças com leucemia linfoide aguda submetidas à quimioterapia (por infusão intravenosa ou por via intratecal). Métodos: Foram avaliadas 14 crianças com idade entre 2 e 12 anos, com diagnóstico de leucemia linfoide aguda. Foram utilizados os seguintes procedimentos: meatoscopia, medidas de imitância acústica, audiometria tonal, audiometria vocal, emissões otoacústicas transientes e potencial evocado auditivo de tronco encefálico. Resultados: Das 14 crianças com limiares auditivos normais, 35,71\% demonstraram alteração no Potencial Evocado Auditivo de Tronco Encefálico, com predomínio de comprometimento de via auditiva em tronco encefálico baixo. Verificou-se que $80 \%$ das crianças com alteração haviam feito uso do metotrexato via intratecal a menos de 30 dias e que $40 \%$ tinham as maiores doses acumulativas de metotrexato por via endovenosa. Conclusão: Crianças com leucemia linfoide aguda submetidas à quimioterapia apresentam comprometimento na via auditiva em tronco encefálico, com predomínio em tronco encefálico baixo.

Palavras-chave: audição; eletrofisiologia; leucemia-linfoma linfoblástico de células precursoras; tratamento farmacológico; metotrexato, criança.

Several factors can compromise the auditory pathway, including the drugs used during chemotherapy.

Both normal cells and cancer cells are destroyed from chemotherapeutic drugs, causing secondary problems ${ }^{1}$ such as ototoxicity and neurotoxicity.

Several chemotherapeutic drugs are used in the treatment of various types of cancer, such as cisplatin, carboplatin, actinomycin, bleomycin, nitrogen mustards (mustine), misonidazole, vincristine, vinblastine ${ }^{2}$, among others.

Acute lymphoblastic leukemia (ALL) is the most common type of cancer found in young children, and may occur in adults ${ }^{3}$. In a study that aimed to estimate the prevalence of hearing loss in children and adolescents with cancer, $30.8 \%$ of the 94 patients treated in 2003 and 2004 in a referral hospital in São Paulo had ALL ${ }^{4}$.

${ }^{1}$ Universidade de São Paulo, Faculdade de Medicina, Curso de Fonoaudiologia, São Paulo SP, Brazil.

${ }^{2}$ Universidade Federal de São Paulo, Setor de Medicina Laboratorial, Departamento de Medicina, São Paulo SP, Brazil.

${ }^{3}$ Universidade de São Paulo, Faculdade de Medicina, Departamento de Pediatria, São Paulo SP, Brazil.

Renata Aparecida LEITE (iD https://orcid.org/0000-0002-5045-7610; Jéssica Sales VOSGRAU ID https://orcid.org/0000-0002-0288-4933; Leticia CORTEZ NETO (iD https://orcid.org/0000-0002-9233-8847; Nayara Pereira SANTOS iD https://orcid.org/0000-0002-2819-7904; Sandro Luiz de Andrade MATAS ID https://orcid.org/0000-0002-0479-2450; Carla Gentile MATAS iD https://orcid.org/0000-0002-9408-7172

Correspondence: Renata Aparecida Leite; Rua Cipotânea, 51;053601-60 São Paulo SP, Brazil; E-mail: realeite@yahoo.com.br

Support: Conselho Nacional de Desenvolvimento Científico e Tecnológico como Bolsa de Pós-Doutorado Processo No 166207/2015-2.

Conflict of interest: There is no conflict of interest to declare.

Received on July 04, 2019; Received in its final form on August 23, 2019; Accepted on September 02, 2019. 
The GBTLI-LLA99 (Grupo Brasileiro de Tratamento da Leucemia na Infância [Brazilian Group for Leukemia Treatment in Childhood ALL-99 Brazilian]5) and BFM95 (developed by the German group Berlin-Frankfurt-Munich) ${ }^{6}$ protocols are used in the treatment of individuals with ALL, and both include the chemotherapeutic drug methotrexate (MTX)

Although several drugs are used in these protocols, MTX is most commonly reported to cause neurotoxicity after its use ${ }^{8,9}$.

MTX is used in the treatment of malignant tumors, both solid and hematological, and can be used in high doses of 3 to $8 \mathrm{~g} / \mathrm{m}^{2}$ or even higher if necessary. MTX can also be used in low doses (10 to $15 \mathrm{mg}$ ) intrathecally for prophylaxis or treatment of leptomeningeal infiltration. Its main indications are ALL and non-Hodgkin's lymphomas, including brain lymphomas and sarcomas (adult and childhood) ${ }^{10}$. The neurotoxicity occasioned by MTX ${ }^{11-13}$ may occur in an acute, subacute, or late form ${ }^{14}$ and can be observed after intrathecal or intravenous administration ${ }^{9,11}$.

The mechanism that MTX causes neurotoxicity is not fully understood, and more than one mechanism may be involved; however, MTX has been observed to have direct toxicity in brain tissue ${ }^{9}$. The location and degree of toxicity are difficult to determine, and there is no clear correlation between the results of auxiliary tests (MRI, radionuclide brain scan, electroencephalography, neuropsychological tests) and the clinical manifestations.

Because MTX can impair both central and peripheral nervous system, its potential neurotoxicity in the central auditory nervous system (CANS) must be considered. Impairment of this region can impede the understanding of speech and, consequently, the development of speech and language in children, possibly hindering the social interaction of individuals.

To evaluate the CANS, auditory evoked potentials (AEPs) are used to assess neuroelectric activity in the auditory pathway from the auditory nerve to the auditory cortex.

Brainstem auditory evoked potential (BAEP) measurement is an objective test that captures the electrical responses to acoustic stimulation generated in the brainstem. This potential consists of seven waves with welldefined generators ${ }^{15,16}$.

BAEPs have been used to investigate ototoxicity in cancer patients undergoing chemotherapy ${ }^{17-19}$, but the investigation of neurotoxicity with this test has rarely been explored.

In a study using BAEPs to assess neurotoxicity in children and adolescents after chemotherapy with cisplatin, an increase was observed in interpeak I-III value that was associated with normal distortion product otoacoustic emissions (DPOE), suggesting neurotoxicity in the auditory pathway in the brainstem. The authors reported the need for further studies to examine neurotoxicity ${ }^{20}$.

Therefore, the objective of this study was to investigate the auditory pathway in the brainstem of children with ALL undergoing chemotherapy (intravenously or intrathecally).

\section{METHODS}

The present study was approved by the Ethics Committee of the institution under number 53924116.0.0000.0068/2016, and data collection was performed only after the parents or guardians signed an informed consent form and the children signed an assent form.

This is a clinical and cross-sectional study that evaluated 14 children ( 8 females; 6 males) aged 2 to 12 years (mean age, 8 years 4 months) who were diagnosed with ALL, had no infiltration into the central nervous system as confirmed by examination of the cerebrospinal fluid, and were undergoing chemotherapy. The volunteers were referred by a public reference hospital in the city of São Paulo, where they were undergoing chemotherapy and outpatient follow-up (1 individual in remission - patient 7).

The audiological and electrophysiological evaluation of hearing was performed in a teaching health center, which required patients to travel, justifying why the sample size was small.

It is noteworthy that in some cases the first assessment was revalued, since the population had complications of chemotherapy, and data collection was performed in two sessions of up to $1 \mathrm{~h} 30 \mathrm{~min}$ when necessary.

The doses of MTX were collected using medical records, and the total dose administered intravenously and/or intrathecally until the date of BAEP measurement was obtained. Dosages, frequency, and duration of drug infusion were established according to the risk group in which the patient was entered.

A Heine ${ }^{\circledast}$ Mini2000" Otoscope was used to examine the ear canal.

The children were subjected to acoustic immittance evaluations (tympanometry and acoustic reflex measurements) to assess possible middle ear impairment (GN Otometrics tympanometer, model Otoflex100). Pure-tone audiometry at frequencies of 500, 1000, 2000, $4000 \mathrm{~Hz}$ (if possible 6000 and $8000 \mathrm{~Hz}$ ) were used to determine auditory thresholds, and speech audiometry (speech recognition threshold - SRT and speech recognition percentage index - SRPI, the latter performed in older children) (Grason Stadler audiometer, model GSI-61, ER-3A earphones, sound booth meeting the ANSI S3.1-1991 standard for the amount of ambient noise).

When obtaining auditory thresholds, the ages of the children were considered, and conditioned play audiometry or pure-tone audiometry using earphones were performed.

To obtain the BAEP measurements, the skin was initially cleaned with an abrasive paste, and the electrodes were fixed to the skin of the individual using an electrolyte paste and adhesive tape (micropore), according to the International Electrode System (IES) 10-20 standard ${ }^{21}$. The impedance values of the electrodes were checked and were below 5kohms.

BAEPs were measured using a click stimulus with rarefied polarity, monoaurally presented at $80 \mathrm{dBnHL}$, at a rate 
of 27.7 stimuli per second, totalizing 2000 stimuli (Universal Smart Box Jr ${ }^{\mathrm{TM}}$ Smart EP, Intelligent Hearing System-ER-3A earphone for BAEP and ER-10D earphone for otoacoustic emissions-OAEs). In cases where it was not possible to perform conventional pure-tone audiometry or transient otoacoustic emissions (TOAEs), the electrophysiological threshold was obtained using the BAEP, with a normal electrophysiological threshold considered to be up to $20 \mathrm{dBnHL}^{22}$.

To obtain this potential, it was necessary for the child to remain seated or laying in a recliner in a comfortable position in a sound and electrically treated room.

After collection, for the acoustic immittance measures, normal results were considered to include the presence of a type A tympanogram pattern ${ }^{23}$ and ipsilateral acoustic reflexes present at frequencies of 500,1000, and $2000 \mathrm{~Hz}$ between 80 and $95 \mathrm{dBHL}^{24}$.

Because the higher frequencies of pure-tone audiometry are important in the evaluation of individuals undergoing chemotherapy, the result was classified as normal when auditory thresholds less than or equal to $15 \mathrm{dBHL}$ were observed at frequencies of 500, 1000, 2000, and $4000 \mathrm{~Hz}$ (children up to 6 years of age) and when auditory thresholds less than or equal to $20 \mathrm{dBHL}$ were observed at frequencies of 250, 500, 1000, 2000, 4000, 6000, and $8000 \mathrm{~Hz}$ (children 7 years old or older).

The speech audiometry result was considered compatible when the SRT showed a response equal to or up to $10 \mathrm{~dB}$ above the mean auditory thresholds obtained in pure-tone audiometry for the frequencies of 500, 1000, and $2000 \mathrm{~Hz}^{25}$ and when the SRPI showed a percentage of accuracy between 90 and $100 \%$ at an intensity of $30 \mathrm{~dB}$ above the $\mathrm{SRT}^{26}$.

Regarding the BAEP, the results were classified as normal and altered for each individual according to whether the absolute latency values of waves I, III, and V, and the interpeak values of I-III, III-V, and I-V were within two standard deviations, as proposed by the literature ${ }^{27}$.

Subsequently, the types of alterations found in each individual were described: alteration in the lower brainstem auditory pathway (increase of latency values of waves III and $\mathrm{V}$ and/or the interpeak values of I-III and I-V); alteration in the upper brainstem auditory pathway (increase of latency values of wave $\mathrm{V}$ and/or interpeak values of III-V and/or $\mathrm{I}-\mathrm{V})$; when the two alterations occurred concomitantly in the same individual, the type of alteration was classified as both.

Results that did not meet the criteria described above were considered altered. For results to be classified as normal, it was necessary for both ears to present results within the normal range. Results for which at least one ear was compromised were classified as altered.

\section{RESULTS}

Regarding the results of the behavioral tests, two children (1 and 6) did not have a conditioned response to the conventional pure-tone audiometry; therefore, the TOAEs were measured. One of the children (subject 1) did not present a response in the TOAE test due to the intense internal noise, while the other (subject 6) had responses at frequencies of 1000, 1500, and $2000 \mathrm{~Hz}$. Both children had electrophysiological thresholds of $20 \mathrm{dBnHL}$ bilaterally in the BAEP measurement.

The other children showed normal results on the behavioral tests.

The BAEP results showed that of the 14 children evaluated, $35.71 \%(1,2,4,8,11)$ had some type of alteration, and the predominant type was auditory impairment in the lower brainstem (80\%) (Tables 1, 2 and 3).

We also observed that $60 \%$ of children $(1,2,4)$ who presented altered BAEPs were younger than 5 years old and that $80 \%$ of the children $(1,2,8,11)$ with alterations had received MTX intrathecally less than 30 days before (Table 1).

The $40 \%$ of children ( 1 and 8 ) who had abnormal BAEP results had the highest cumulative doses of MTX administered intravenously ( $8.000 \mathrm{mg}$, subject 1; $7.600 \mathrm{mg}$, subject 2) and intrathecally (72 mg, subject 1; 99 mg, subject 2) (Table 1).

\section{DISCUSSION}

Although data from the literature ${ }^{4}$ show that ALL occurs more frequently in males, in the present study, our sample included mostly females. This may have occurred because the sample number was small.

Conductive impairment was only observed in children younger than 5 years ( 3 years 7 months), while upper airway impairment was present in both younger and older children. This hindered the measurement of OAEs; therefore, this procedure was performed only in children who did not undergo puretone audiometry. These findings are consistent with reports in the literature of individuals undergoing chemotherapy who have both complaints of otitis and upper airway infection ${ }^{4}$.

Chemotherapeutic drugs do not differentiate normal cells from cancer cells; therefore, several types of normal cells are destroyed, causing secondary problems ${ }^{1}$, such as ototoxicity ${ }^{4}$. The results of the behavioral tests obtained in the present study showed that the peripheral hearing of children at the frequencies conventionally evaluated was not impaired by chemotherapy because all children had thresholds within the normal range for their age.

However, analysis of the TOAEs for subject 6 (Table 1) showed responses at frequencies of 1000, 1500, and $2000 \mathrm{~Hz}$ and no response at frequencies of 3000 and $4000 \mathrm{~Hz}$ (higher frequencies) bilaterally. Due to the absence of response to the 3000 and $4000 \mathrm{~Hz}$ frequencies, the electrophysiological threshold was obtained using the BAEP, which was $20 \mathrm{dBnHL}$ bilaterally. The medical records showed that this individual had been undergoing chemotherapy for several months, and one of the drugs used was vincristine at a dose of $4.400 \mathrm{mg}$, 
which, according to the literature, is considered an ototoxic $\operatorname{drug}^{28}$. These findings suggest that alterations occur in the cochlea and are first detected by the TOAE responses and later by the auditory thresholds obtained in pure-tone audiometry, which would explain the electrophysiological threshold of $20 \mathrm{dBHL}$ bilaterally. In a study involving auditory monitoring in patients undergoing chemotherapy, the TOAE results showed that a response to frequencies of 1000 and $2000 \mathrm{~Hz}$ was observed until the end of treatment, while a progressive increase in the absence of responses to frequencies of 3000 and $4000 \mathrm{~Hz}$ was observed during treatment ${ }^{29}$.

In the present study, we found that $5(35.71 \%)$ of the individuals who underwent audiological and electrophysiological assessment of hearing (Tables 1 and 2) showed impairment in the auditory pathway in its most central portion, demonstrating the importance of peripheral and central auditory assessment in this population.

According to the BAEP results, the five individuals mentioned above had some type of alteration, and the predominant type was auditory impairment in the lower brainstem (Tables 1 and 2). These findings suggest possible impairment by MTX, as the literature emphasizes that this drug can cause adverse effects, such as neurotoxicity ${ }^{11-13}$. In addition, studies have reported that neurotoxicity can occur in an acute, subacute, or chronic form ${ }^{14}$ and can be observed after intrathecal or intravenous administration of MTX ${ }^{9,11}$. In the present study, it was also observed that the majority of children with alterations had used MTX intrathecally less than 30 days prior.

Other authors have further reported that acute and subacute forms of neurotoxicity may occur during ALL treatment, generally manifesting as neurological signs. In some cases, neurotoxicity is transient and benign, and in other cases, it can be severe and debilitating, leading to permanent neurological deficits.

Because BAEP measurement was not performed prior to MTX administration, and follow-up was not performed, it was not possible to determine when auditory nerve impairment and/or brainstem impairment occurred or the duration of such impairment. According to the literature, the mechanism by which MTX causes neurotoxicity is not fully

Table 2. Distribution of the occurrence of normal and abnormal results and types of alterations on the BAEP observed in children undergoing chemotherapy with methotrexate.

\begin{tabular}{|c|c|c|c|c|c|c|}
\hline BAEP & \multicolumn{3}{|c|}{$\mathrm{n}$} & \multicolumn{3}{|c|}{$\%$} \\
\hline Normal & \multicolumn{3}{|c|}{9} & \multicolumn{3}{|c|}{64.29} \\
\hline Abnormal & \multicolumn{3}{|c|}{5} & \multicolumn{3}{|c|}{35.71} \\
\hline \multirow{2}{*}{$\begin{array}{l}\text { Type of } \\
\text { alteration }\end{array}$} & \multicolumn{2}{|c|}{ Low brainstem } & \multicolumn{2}{|c|}{ High brainstem } & \multicolumn{2}{|c|}{ Both } \\
\hline & $n$ & $\%$ & $n$ & $\%$ & $n$ & $\%$ \\
\hline BAEP & 4 & 80 & 1 & 20 & 0 & 0 \\
\hline
\end{tabular}

BAEP: brainstem auditory evoked potential.

Table 1. Characterization of the sample as the use of methotrexate, BAEP result, cerebrospinal fluid collection, and the child's age.

\begin{tabular}{|c|c|c|c|c|c|c|c|c|c|c|c|c|}
\hline Individuals & age & $\begin{array}{l}\text { intravenous } \\
\text { MTX } \\
\text { cumulative } \\
\text { dosage }\end{array}$ & $\begin{array}{l}\text { dosage of } \\
\text { the last } \\
\text { administration } \\
\text { of MTX }\end{array}$ & $\begin{array}{c}\text { days of last } \\
\text { administration }\end{array}$ & $\begin{array}{l}\text { intrathecal } \\
\text { MTX } \\
\text { cumulative } \\
\text { dosage }\end{array}$ & $\begin{array}{l}\text { dosage of } \\
\text { the last } \\
\text { administration } \\
\text { of MTX }\end{array}$ & $\begin{array}{c}\text { days of last } \\
\text { administration }\end{array}$ & normal & abnormal & $\begin{array}{l}\text { type of } \\
\text { alteration }\end{array}$ & $\begin{array}{l}\text { time between } \\
\text { cerebrospinal } \\
\text { fluid collection } \\
\text { and ABR (days) }\end{array}$ & $\begin{array}{c}\text { Result } \\
\text { Liquor } \\
\text { (neoplastic } \\
\text { cells) }\end{array}$ \\
\hline 1 & $3 a 6 m$ & $7.600 \mathrm{mg}$ & $3.800 \mathrm{mg}$ & 54 & $72 \mathrm{mg}$ & $12 \mathrm{mg}$ & 22 & & $x$ & $\begin{array}{c}\text { low } \\
\text { brainstem }\end{array}$ & 7 & negative \\
\hline 2 & $4 a 3 m$ & $1.447 \mathrm{mg}$ & $740 \mathrm{mg}$ & 6 & $48 \mathrm{mg}$ & $12 \mathrm{mg}$ & 1 & & $\mathrm{x}$ & $\begin{array}{c}\text { low } \\
\text { brainstem }\end{array}$ & 11 & negative \\
\hline 3 & $4 a 4 m$ & $2.700 \mathrm{mg}$ & $1.400 \mathrm{mg}$ & 38 & $36 \mathrm{mg}$ & $12 \mathrm{mg}$ & 38 & $x$ & & & 37 & negative \\
\hline 4 & $4 a 4 m$ & $1.600 \mathrm{mg}$ & $200 \mathrm{mg}$ & 67 & $36 \mathrm{mg}$ & $12 \mathrm{mg}$ & 113 & & $x$ & $\begin{array}{c}\text { low } \\
\text { brainstem }\end{array}$ & 103 & negative \\
\hline 5 & $5 \mathrm{a} 2 \mathrm{~m}$ & $710 \mathrm{mg}$ & $150 \mathrm{mg}$ & 31 & $48 \mathrm{mg}$ & $15 \mathrm{mg}$ & 54 & $x$ & & & 19 & negative \\
\hline 6 & $3 a 3 m$ & $2.229 \mathrm{mg}$ & $1.100 \mathrm{mg}$ & 65 & $64 \mathrm{mg}$ & $12 \mathrm{mg}$ & 11 & $x$ & & & 3 & negative \\
\hline 7 & $6 a 8 m$ & $4.390 \mathrm{mg}$ & $330 \mathrm{mg}$ & 102 & $60 \mathrm{mg}$ & $12 \mathrm{mg}$ & 126 & $x$ & & & 193 & negative \\
\hline 8 & $10 \mathrm{a} 8 \mathrm{~m}$ & $8.000 \mathrm{mg}$ & $5.000 \mathrm{mg}$ & 43 & $99 \mathrm{mg}$ & $12 \mathrm{mg}$ & 13 & & $x$ & $\begin{array}{c}\text { low } \\
\text { brainstem }\end{array}$ & 8 & negative \\
\hline 9 & $12 \mathrm{a} 6 \mathrm{~m}$ & $5.000 \mathrm{mg}$ & $5.000 \mathrm{mg}$ & 6 & $30 \mathrm{mg}$ & $15 \mathrm{mg}$ & 21 & $x$ & & & 1 & negative \\
\hline 10 & $11 a$ & $2.250 \mathrm{mg}$ & $250 \mathrm{mg}$ & 15 & $24 \mathrm{mg}$ & $12 \mathrm{mg}$ & 155 & $x$ & & & 27 & negative \\
\hline 11 & $10 \mathrm{a} 5 \mathrm{~m}$ & $1.160 \mathrm{mg}$ & $920 \mathrm{mg}$ & 36 & $45 \mathrm{mg}$ & $15 \mathrm{mg}$ & 7 & & $x$ & $\begin{array}{c}\text { high } \\
\text { brainstem }\end{array}$ & 7 & negative \\
\hline 12 & $9 a 7 m$ & $2.300 \mathrm{mg}$ & $200 \mathrm{mg}$ & 9 & $84 \mathrm{mg}$ & $12 \mathrm{mg}$ & 9 & $x$ & & & 9 & negative \\
\hline 13 & $11 \mathrm{a} 6 \mathrm{~m}$ & $4.550 \mathrm{mg}$ & $25 \mathrm{mg}$ & 2 & $24 \mathrm{mg}$ & $12 \mathrm{mg}$ & 2 & $x$ & & & 19 & negative \\
\hline 14 & $12 \mathrm{a} 8 \mathrm{~m}$ & $2.690 \mathrm{mg}$ & $30 \mathrm{mg}$ & 79 & $15 \mathrm{mg}$ & $15 \mathrm{mg}$ & 109 & $x$ & & & 18 & negative \\
\hline
\end{tabular}

MTX: methotrexate; BAEP: brainstem auditory evoked potential. 
understood, and more than one mechanism may be involved, but MTX has been shown to have an immediate effect on nerve tissue ${ }^{9}$. The findings of our study suggest that this effect occurred because children exhibited impairment of the auditory nerve/brainstem at 1,7 , and 13 days after administration of MTX.

It was not possible to establish the minimum (or exact) amount of drug likely to impair the lower brainstem region using the results of this study. However, we found that $40 \%$ of children who had abnormal BAEP results received the highest cumulative doses of MTX intravenously (8.000 mg, subject 1; $7.600 \mathrm{mg}$, subject 2) and intrathecally (72 mg, subject 1; $99 \mathrm{mg}$, subject 2) (Table 1), which are doses considered to be high according to the literature ${ }^{10}$.

In addition, the location and degree of toxicity that MTX causes in the central nervous system are difficult to establish $^{9}$, but in the present study most of the impairment occurred in the lower brainstem. The only study found in the literature that used BAEPs to evaluate the central auditory pathway of individuals undergoing chemotherapy showed that these individuals exhibited an increase in the interpeak I-III value ${ }^{20}$. This result is suggestive of impairment in the lower brainstem auditory pathway.

Studies of BAEP measurement in individuals receiving MTX were not found in the literature; however, in a study that assessed motor evoked potentials, delayed conduction of the stimulus in the peripheral motor nerve as well as impairment of the central nervous system were observed after intrathecal MTX administration ${ }^{30}$.

It is known that, ABR waves I, III, and V are the largest and most frequently observed waves when compared to waves II and IV that may not be present even in normal individuals. Thus, the present study opted for the analysis of waves I, III, and V and their interpeaks I-III, III-V, and I-V. Normal wave I latency values were observed in all evaluated individuals, and the same was not observed for waves III and V and / or interpeaks I-III, I-V, III-V.

As most children in the present study exhibited alterations in the lower brainstem, it can be inferred that a deficit in nerve conduction of the acoustic stimulus was present in the region proximal to the brainstem of the auditory nerve (wave II) (although the values were not obtained), which is part of the final structure of the peripheral auditory system ${ }^{31}$, that interfered with the latency value of wave III, or there may have been a deficit in the cochlear nucleus region (wave III) located in the brainstem - the first structure of the central auditory nervous system ${ }^{31}$.

In the present study, another important finding was the observation that children younger than five years old were the most susceptible to chemotherapy because most had some type of impairment in the auditory pathway. These findings corroborate a previous study that showed that children and elderly people undergoing chemotherapy are most susceptible to auditory alterations ${ }^{32}$.

Table 3. BAEP latency values obtained in the sample.

\begin{tabular}{|c|c|c|c|c|c|c|c|c|c|c|c|c|c|}
\hline \multirow[b]{3}{*}{ Individuals } & \multirow[b]{3}{*}{ age } & \multicolumn{6}{|c|}{ Latency (ms) } & \multicolumn{6}{|c|}{ Interpeak (ms) } \\
\hline & & \multicolumn{2}{|c|}{ I } & \multicolumn{2}{|c|}{ III } & \multicolumn{2}{|c|}{$\mathrm{V}$} & \multicolumn{2}{|c|}{ I-III } & \multicolumn{2}{|c|}{ III-V } & \multicolumn{2}{|c|}{$I-V$} \\
\hline & & Right & Left & Right & Left & Right & Left & Right & Left & Right & Left & Right & Left \\
\hline 1 & $3 a 6 m$ & 1.75 & 1.45 & 4.20 & 4.15 & 5.90 & 5.90 & 2.45 & 2.70 & 1.70 & 1.75 & 4.15 & 4.45 \\
\hline 2 & $4 a 3 m$ & 1.70 & 1.65 & 3.95 & 4.10 & 5.70 & 5.85 & 2.25 & 2.45 & 1.75 & 1.75 & 4.00 & 4.20 \\
\hline 3 & $4 a 4 m$ & 1.60 & 1.45 & 3.80 & 3.80 & 5.65 & 5.55 & 2.20 & 2.35 & 1.85 & 1.75 & 4.05 & 4.10 \\
\hline 4 & $4 a 4 m$ & 1.65 & 1.55 & 4.05 & 4.00 & 5.85 & 5.70 & 2.40 & 2.45 & 1.80 & 1.70 & 4.20 & 4.15 \\
\hline 5 & $5 a 2 m$ & 1.60 & 1.50 & 3.80 & 3.80 & 5.75 & 5.65 & 2.20 & 2.30 & 1.95 & 1.85 & 4.15 & 4.15 \\
\hline 6 & $3 a 3 m$ & 1.60 & 1.55 & 3.75 & 3.80 & 5.60 & 5.65 & 2.15 & 2.25 & 1.85 & 1.85 & 4.00 & 4.10 \\
\hline 7 & $6 a 8 m$ & 1.85 & 1.70 & 3.70 & 3.85 & 5.70 & 5.75 & 1.85 & 2.15 & 2.00 & 1.90 & 3.85 & 4.05 \\
\hline 8 & $10 a 8 m$ & 1.25 & 1.25 & 3.95 & 3.85 & 5.70 & 5.80 & 2.70 & 2.60 & 1.75 & 1.95 & 4.45 & 4.55 \\
\hline 9 & $12 \mathrm{a} 6 \mathrm{~m}$ & 1.55 & 1.55 & 3.85 & 3.75 & 5.70 & 5.65 & 2.30 & 2.20 & 1.85 & 1.90 & 4.15 & 4.10 \\
\hline 10 & $11 a$ & 1.65 & 1.45 & 3.75 & 3.75 & 5.80 & 5.50 & 2.10 & 2.30 & 2.05 & 1.75 & 4.15 & 4.05 \\
\hline 11 & $10 \mathrm{a} 5 \mathrm{~m}$ & 1.75 & 1.75 & 3.90 & 3.90 & 6.00 & 6.00 & 2.15 & 2.15 & 2.10 & 2.10 & 4.25 & 4.25 \\
\hline 12 & $9 a 7 m$ & 1.75 & 1.65 & 3.75 & 3.70 & 5.60 & 5.55 & 2.00 & 2.05 & 1.85 & 1.85 & 3.85 & 3.90 \\
\hline 13 & $11 \mathrm{a} 6 \mathrm{~m}$ & 1.75 & 1.55 & 3.65 & 3.70 & 5.50 & 5.50 & 1.95 & 2.10 & 1.80 & 1.85 & 3.75 & 3.95 \\
\hline 14 & $12 \mathrm{a} 8 \mathrm{~m}$ & 1.75 & 1.75 & 3.85 & 3.85 & 5.70 & 5.75 & 2.10 & 2.10 & 1.85 & 1.90 & 3.95 & 4.00 \\
\hline
\end{tabular}

BAEP: brainstem auditory evoked potential. 
Although MTX is considered neurotoxic, it is important to highlight that there is interindividual variability, which may be due to genetic susceptibility, having as participants the following genes involved: megaline, glutathione S-transferase, cross-complementation group's excision repair 1 and 2, acylphosphatase 2, and mutations in mitochondrial genes $^{33}$. Such variability would explain lower dose individuals in the present study with impairments after drug use (individual 4 intrathecal) and individual with higher dose without alteration (individual 12 intrathecal).

Considering that all individuals in the present study underwent cerebrospinal fluid examination with negative results during the investigation of neoplastic cells (suggesting absence of infiltration into the central nervous system) and that, among the drugs used in the treatment of ALL, MTX is most often referred to by authors as being the main drug related to neurotoxicity, we can infer that the findings of brainstem auditory pathway impairment in the present study might have been caused by the administration of MTX in this population.

Because the auditory nerve is responsible for the tonotopic organization of frequencies (low and high) ${ }^{31}$ (wave II of the BAEP) and the cochlear nucleus is responsible for listening in noisy conditions ${ }^{34}$ (wave III of the BAEP), impairment in one of these regions, even if temporary, especially in young children, can compromise the development of speech and language and impair their social interaction (family, school).

Although this population is difficult to assess due to the complications of chemotherapy, behavioral assessment of auditory processing would be indicated in individuals with alterations in BAEP, as well as in those with complaints and normal hearing thresholds, aiming at a better direction in the therapeutic treatment and stimulation of impaired auditory skills.

The present study demonstrated that BAEP measurement is a useful tool in the evaluation of individuals undergoing chemotherapy, which demonstrated the importance of peripheral and central auditory evaluation in this population, in addition to audiological monitoring during chemotherapy. Thus, therapeutic strategies can be implemented early to decrease future impairments in this population who are undergoing acquisition and development of speech and language.

Further prospective studies with a larger number of individuals and with BAEP measurements conducted prior to chemotherapy should be performed to better define the auditory impairment of these patients.

In conclusion, children with ALL undergoing chemotherapy exhibit impairment of the brainstem auditory pathway, and the main impairment was located in the auditory pathway in the lower brainstem.

\section{References}

1. Alcoser PW, Rodgers C. Treatment strategies in childhood cancer.J Pediatr Nurs. 2003 Apr;18(2):103-12. https://doi.org/10.1053/jpdn.2003.10

2. Federación Federación de Asociaciones de Implantados Cocleares de España (AICE). Medicamentos Ototóxicos. 2009;22:32. Available from: http://implantecoclear.org/index.php?option=com_content\&view=ar ticle\&id=188: medicamentos-ototoxicos\&catid=114: ototoxicos

3. Brasil. Ministério da Saúde. Instituto Nacional do Câncer José Alencar Gomes da Silva (INCA). Estimativa 2018: Incidência de Câncer no Brasil. Rio de Janeiro (RJ): INCA; 2018. Available from: http://www1.inca.gov.br/inca/Arquivos/estimativa-2018.pdf

4. Silva AM, Latorre MRDO, Cristofani LM, Odone Filho V. A prevalência de perdas auditivas em crianças e adolescentes com câncer. Rev Bras Otorrinolaringol. 2007;73(5):608-614. http://doi.org/10.1590/ S0034-72992007000500005

5. Brasil. Ministério da Saúde. Instituto Nacional do Câncer José Alencar Gomesda Silva (INCA Condutas do INCA). Leucemias Agudas na Infância e na Adolescência. Rev Bras Cancerol. 2001;47(3):245-57.

6. Möricke A, Reiter A, Zimmermann M, Gadner H, Stanulla M, Dördelmann $M$, et al. Risk-adjusted therapy of acute lymphoblastic leukemia can decrease treatment burden and improve survival: Treatment results of 2169 unselected pediatric and adolescent patients enrolled in the trial ALL-BFM 95. Blood. 2008 May;111(9):4477-89. https://doi.org/10.1182/blood-2007-09-112920

7. Cazé MA, Bueno D, Santos MEF. Estudo referencial de um protocolo quimioterápico para leucemia linfocítica aguda infantil. Rev HCPA. 2010 Apr;30(1):5-12

8. Shuper A, Stark B, Kornreich L, Cohen IJ, Aviner S, Steinmetz A, et al. Methotrexate treatment protocols and the central nervous system: significant cure with significant neurotoxicity. J Child Neurol. 2000 Sep;15(9):573-80. https://doi.org/10.1177/088307380001500902
9. Shuper A, Stark B, Kornreich L, Cohen IJ, Avrahami G, Yaniv I. Methotrexate-related neurotoxicity in the treatment of childhood acute lymphoblastic leukemia. IMAJ. 2002 Dec;4(11):1050-3.

10. Reutenauer S, Chauveau D, Récher C. Surdosage au méthotrexate: complications, prise en charge et prévention High-dose methotrexate: Toxicity, management and prevention. Réanimation. 2009 Oct;18(7):654-8. https://doi.org/10.1016/j. reaurg.2009.06.018

11. Bhojwani D, Sabin ND, Pei D, Yang JJ, Khan RB, Panetta JC, et al. Methotrexate-Induced neurotoxicity and leukoencephalopathy in childhood acute lymphoblastic leukemia.J Clin Oncol. 2014;32(9):949-59. https://doi.org/10.1200/JC0.2013.53.0808

12. Jabbour E, O’Brien S, Kantarjian H, Garcia-Manero G, Ferrajoli A, Ravandi F, et al. Neurologic complications associated with intrathecal liposomal cytarabine given prophylactically in combination with high-dose methotrexate and cytarabine to patients with acute lymphocytic leukemia. Blood. 2007 Apr;109(8):3214-8. https://doi.org/10.1182/ blood-2006-08-043646

13. Guzmán T, Rubio S, Poyatos-Ruiz LL, Navarro G. High-doses of methotrexate in osteosarcoma. Does it adjust to a real body surface area? Rev OFIL. 2008;27(1):88-90.

14. Gaies E, Jebabli N, Trabelsi S, Salouage I, Charfi R, Lakhal $\mathrm{M}$, et al. Methotrexate Side Effects: Review Article. J Drug Metab Toxicol. 2012;3(4):1-5. https://doi.org//10.4172/21577609.1000125

15. Durrant JD, Ferraro JA. Potenciais Evocados Auditivos de curta latência: eletrococleografia e audiometria de tronco encefálico. In: Musiek FE, Rintelmann WF. Perspectivas atuais em avaliação auditiva. São Paulo: Manole; 2001.193-238. 
16. Møller AR, Janetta P, Bennet M, Møller MB. Intracranially recorded responses from the human auditory nerve: new insights into the origin of brain stem evoked potentials (BSEPS). Electroencephalogr Clin Neurophysiol. 1981 Jul;52(1):18-27. https:// doi.org/10.1016/0013-4694(81)90184-x

17. Coupland SG, Ponton CW, Eggermont JJ, Bowen TJ, Grant RM. Assessment of cisplatin-induced ototoxicity using derived-band ABRs. Int J Pediatr Otorhinolaryngol. 1991 Oct;22(3):237-48. https:// doi.org/10.1016/0165-5876(91)90078-p

18. Dille MF, Ellingson RM, McMillan GP, Konrad-Martin D. ABR Obtained from time-efficient train stimuli for cisplatin ototoxicity monitoring. J Am Acad Audiol. 2013 Oct;24(9):769-81. https://doi.org/10.3766/ jaaa.24.9.2

19. De Lauretis A, De Capua B, Barbieri MT, Bellussi L, Passàli D. ABR evaluation of ototoxicity in cancer patients receiving cisplatin or carboplatin. Scand Audiol. 1999;28(3):139-43.

20. Viana LM, Sampaio ALL, Maia NA, Junqueira RMP, Venosa AR, Oliveira CACP. Auditory Brainstem Responses (ABR) changes in children treated with high doses cisplatin. Int Tinnitus J. 2012;17(2):158-62. https://doi.org/10.5935/0946-5448.20120028

21. Klem GH, Lüders HO, Jasper HA, Elger C. The ten-twenty system of the International Federation. The International Federation of Clinical Neurophysiology. Electroencephalogr Clin Neurophysiol Suppl. 1958;52:3-6.

22. Sousa LCA de, Piza MR de T, Alvarenga KF, Cóser PL. Eletrofisiologia da Audição e Emissões Otoacústicas. Princípios e Aplicações Clínicas. Riberão Preto: Book Toy, 2016. p. 49-87.

23. Jerger J. Clinical experience with impedance audiometry. Arch Otolaryngol. 1970 Oct;92(4):311-24. https://doi.org/10.1001/ archotol.1970.04310040005002

24. Carvallo RMM, Carvalho M, Ishida IM. Auditory profile in individuals with and without CAPD. In: $12^{\text {th }}$ Annual Convention Exposition of the American Academy of Audiology. Chicago, USA; 2000. p.195.

25. Santos TMM, Russo ICP. Logoaudiometria. In: Santos TMM, Russo ICP. A prática da audiologia clínica. 4. ed. São Paulo: Cortez; 1986. p. 81-98.
26. Jerger J, Speaks C, Trammell J. A new approach to speech audiometry J Speech Hear Disord. 1968 Nov;33(4):318-28.

27. Gonçalves IC, Andrade CRF, Matas CG. Auditory Processing of Speech and Non-Speech Stimuli in Children who Stutter: Electrophysiological Evidences. Brain Disord Ther. 2015;4(5):1-5. https://doi.org/10.4172/2168-975X.1000199

28. Costa JC, Buss $\mathrm{CH}$. Análise de prontuários de pacientes oncológicos quanto ao monitoramento auditivo. Rev CEFAC. 2009 Apr/Jun;11(2):323-30. http://dx.doi.org/10.1590/S151618462009000200018

29. Garcia AP, lório MCM, Petrilli AS. Monitoramento da audição de pacientes expostos à cisplatina. Rev Bras Otorrinolaringol. 2003 Mar/Apr;69(2):215-21. http://doi.org/10.1590/S003472992003000200011

30. Harila-Saari AH, Huuskonen UE, Tolonen U, Vainionpää LK, Lanning BM. Motor nervous pathway function is impaired after treatment of childhood acute lymphoblastic leukemia: A study with motor evoked potentials. Med Pediatr Oncol. 2001 Mar;36(3):345-51. https://doi. org/10.1002/mpo.1084

31. Musiek FE, Baran JA. Overview of the anatomy and Physiology of the Auditory System. San Diego CA.: Plural Publishing INC; 2016. (The Auditory System - Anatomy, Physiology and Clinical Correlates. 1- 37).

32. Schacht J, Talaska AE, Rybak LP. Cisplatin and Aminoglycoside antibiotics: hearing loss and its prevention. Anat Rec (Hoboken). 2012 Nov;295(11):1837-50. https://doi.org/10.1002/ar.22578

33. Brock PR, Knight KR, Freyer DR, Campbell KC, Steyger PS, Blakley BW, et al. Platinum-induced ototoxicity in children: a consensus review on mechanisms, predisposition, and protection, including a new International Society of Pediatric Oncology Boston Ototoxicity Scale. J Clin Oncol. 2012 Jul 1;30(19):2408-17. https://doi.org/10.1200/ JCO.2011.39.1110

34. Masterton RB, Granger EM, Glendenning KK. Role ofacoustic stria in hearing: Mechanism for enhancement of sound detection in cats. Hear Res. 1994:73(2):209-22.

\section{ERRATUM}

In the manuscript "Brainstem auditory pathway of children with acute lymphoid leukemia on chemotherapy with methotrexate", DOI: 10.1590/0004-282X20190139, published in the Arq. Neuro-Psiquiatr. 2020;78(2):63-69. Epub Jan 31, 2020, on page 63.

Where it reads:

Carla Gentile MATAS (ID https://orcid.org/0000-0001-5861-3342

\section{It should read:}

Carla Gentile MATAS iD https://orcid.org/0000-0002-9408-7172 